\title{
Markers linked to the $b c-3$ gene conditioning resistance to bean common mosaic potyviruses in common bean
}

\author{
Gerardine Mukeshimana ${ }^{1}$, Astrid Pañeda ${ }^{2}$, Cristina Rodríguez-Suárez ${ }^{2}$, Juan José Ferreira ${ }^{3}$, \\ Ramón Giraldez ${ }^{2}$ \& James D. Kelly ${ }^{4, *}$ \\ ${ }^{1}$ National University of Rwanda, NUR, Butare, Rwanda $;{ }^{2}$ Department of Biología Funcional, University of Oviedo, \\ 33006 Oviedo, Spain; ${ }^{3}$ SERIDA, 33300 Villaviciosa (Asturias), Spain; ${ }^{4}$ Crop and Soil Sciences, Michigan State \\ University, East Lansing MI 48824, USA (*author for correspondence; e-mail: kellyj@msu.edu)
}

Received 20 October 2004; accepted 17 May 2005

Key words: AFLP, bean common mosaic virus (BCMV), bean common mosaic necrosis virus (BCMNV), gene pyramiding, Phaseolus vulgaris, RAPD, STS markers

\section{Summary}

Necrotic strains of bean common mosaic potyviruses are becoming increasingly problematic in bean growing areas of Africa and Europe. Pyramiding epistatic resistance genes provides the most effective long-term strategy for disease control against all known strains of the virus. Indirect selection using tightly linked markers should facilitate the breeding of desired epistatic resistance gene combinations. In common bean, the most effective strategy for broad spectrum control of the bean common mosaic potyviruses is to combine $I$ and $b c-3$ genes. We describe the use of near-isogenic lines and segregating populations from different gene pools combined with bulked segregant analysis to identify markers tightly linked with the recessive $b c-3$ gene that conditions resistance to all strains of bean common mosaic necrosis virus. We identified a RAPD marker, OG6 $6_{595}$, linked at $3.7 \mathrm{cM}$ from the $b c-3$, and the marker was used to confirm the location of $b c-3$ gene on bean linkage group B6. A codominant AFLP marker, $\mathrm{E}_{A C A} \mathrm{M}_{C G G}-169 / 172$ was identified and linked at $3.5 \mathrm{cM}$ from the $b c-3$ and the AFLP and OG6 595 markers flanked the $b c-3$ gene. The AFLP marker was converted to the STS marker $\mathrm{SE}_{A C A} \mathrm{M}_{C G G}-134 / 137$ which showed co-segregation with the original AFLP marker. The $134 \mathrm{bp}$ fragment associated with resistance was linked with the $b c-3$ gene present in a diverse group of bean genotypes except in two kidney bean lines. The OG6 595 marker mapped on B6 supported independence of $b c-3$ from the $I$ gene located on B2, which provides the opportunity to readily combine both genes in a single bean cultivar for broad spectrum resistance to bean common mosaic potyviruses.

\section{Introduction}

Bean Common Mosaic Virus (BCMV) and Bean Common Mosaic Necrosis Virus (BCMNV) are the most common and destructive potyviruses known to infect common bean (Phaseolus vulgaris L.) worldwide (Drijfhout, 1978; McKern et al., 1992). Both viruses are seedborne and transmitted by several aphid species in a non-persistent manner (Drijfhout, 1978). These viruses have been reported in common bean in many parts of the world including Europe (Drijfhout, 1978; Sáiz et al., 1995), U.S. (Kelly et al., 1983; Provvidenti et al., 1984), Canada (Tu, 1986), Mexico (Flores-Estévez et al., 2003) and Africa (Silbernagel et al., 1986; Spence \& Walkey, 1995; Sengooba et al., 1997; Njau \& Lyimo, 2000). BCMNV likely evolved more recently in the African continent (Spence \& Walkey, 1995) and recombination has been observed between strains of BCMV and BCMNV (Silbernagel et al., 2001).

The most effective ways to prevent susceptible bean plants from becoming infected with BCMV and $\mathrm{BCMNV}$ is through the production of virus-free seed stocks in geographic regions were the viruses do not exist (Hart \& Saettler, 1981) or through the use of genetic resistance (Drijfhout, 1978). Among the methods available to prevent virus infection in common 
bean, genetic resistance is the most cost effective and durable (Drijfhout, 1978; Kelly et al., 1995; Miklas et al., 2000). In East Africa where BCMNV is found in wild legumes (Sengooba et al., 1997; Spence \& Walkey, 1995), the only effective way to control these viruses is to plant resistant cultivars, otherwise susceptible bean plants can become infected from alternate hosts, growing adjacent to bean fields (Coyne et al., 2003).

Dominant and recessive resistance genes condition resistance to $\mathrm{BCMV}$ and $\mathrm{BCMNV}$ in common bean (Ali, 1950; Drijfhout, 1978, 1991). The dominant inhibitory $I$ gene (Ali, 1950) conditions a classic hypersensitive resistance response whereas the recessive genes are constitutively expressed and act by restricting virus replication or movement within the plant (Kelly, 1997; Kelly et al., 1995, 2003). The dominant form of resistance to BCMNV and BCMV conferred by the $I$ gene has been a source of resistance against a wide range of BCMV strains for the last half century (Kelly, 1997). However, in the presence of temperature-insensitive necrotic-inducing (TINI) strains of BCMNV, the $I$ gene is a production concern because the hypersensitive response results in vascular necrosis and death of infected plants (Drijfhout, 1991). The presence of the $I$ gene in bean cultivars in Central and Eastern Africa where BCMNV strains exist has been such a serious problem that breeders in those regions select against the $I$ gene (Silbernagel et al., 1986). Since dominant and recessive resistance genes have distinctly different mechanisms of resistance, bean breeders can utilize gene pyramiding as a strategy to enhance the durability of resistance (Kelly et al., 1995). Plant death resulting from the single $I$ gene can be prevented by incorporating into new cultivars a series of recessive genes that confer resistance to the specific TINI strains of BCMNV (Kelly, 1997).

Recessive resistance genes have been demonstrated to be effective and long lasting in controlling diseases caused by viruses (Fraser, 1992; Johansen et al., 2001; Harrison, 2002). While little is known about the nature of resistance, two hypotheses could explain the role of recessive genes in virus resistance (Revers et al., 1999). The resistant host may lack a host function essential for critical steps in viral pathogenicity, and consequently the dominant allele encodes a host factor, which is required for the virus to replicate and/or move in the susceptible host; or the susceptibility allele encodes a dominant negative regulator of resistance. These hypotheses may explain why virulence against recessive resistance is rare since it is unlikely that a virus could mutate to overcome a missing or defective host function.

In common bean, three strain specific recessive loci $b c-1, b c-1^{2} ; b c-2, b c-2^{2}$; and $b c-3$ control resistance to BCMV and BCMNV (Drijfhout, 1978, 1991). The fourth recessive locus conditioning resistance is a strain nonspecific $b c-u$ gene that is necessary for the full expression of all strain specific recessive genes in the absence of the $I$ gene (Drijfhout, 1978). With the exception of the $b c-2$ locus, the other single recessive resistance genes are functional in the presence of the $I$ gene (Kelly et al., 1995). Most of the resistance genes have been mapped to independent loci on the bean integrated linkage map (Freyre et al., 1998): The $I$ gene maps to linkage group B2 (Freyre et al., 1998); the $b c$ $1^{2}$ allele maps to B3 (Freyre et al., 1998; Kelly et al., 2003; Miklas et al., 2000); the $b c-u$ also resides on B3 due to its loose linkage with $b c-1$ locus (Strausbaugh et al., 1999); and the $b c-3$ gene maps to B6 (Gepts, 1999; Kelly et al., 2003). Bean breeders have exploited the independence of these resistance genes in the development of cultivars with pyramided resistance as the preferred strategy in breeding for durable resistance to BCMV and BCMNV (Kelly et al., 1994).

Epistatic interactions occur between the different resistance genes when bean plants are inoculated with the NL 3 strain of BCMNV: $b c-3$ masks the effect of the $I, b c-2^{2}$ and $b c-1^{2}$ genes; and $b c-2^{2}$ masks the $b c$ $1^{2}$ gene (Kelly et al., 1995). Because of the epistatic interaction between $b c-3$ and $I$, the effect of the $I$ gene cannot be detected phenotypically in the presence of the $b c-3$ gene. The $b c-3$ gene confers resistance to all known strains of BCMNV and BCMV in the presence of the dominant $I$ gene. In the presence of the recessive $i$ gene, $b c-3$ requires the presence of $b c-u$ to be fully expressed while $b c-u$ is not required in the presence of the dominant $I$ gene. Cultivars with $I, b c-3$ and $b c-u, b c-3$ combinations are immune to all strains of $\mathrm{BCMV}$ and BCMNV while $i, b c-3$ genotypes are resistant to all strains of BCMNV but susceptible to some strains of BCMV (Miklas et al., 1998). To develop complete resistance to both potyviruses, bean breeders have used indirect selection by deploying molecular markers linked to the $I$ gene (Haley et al., 1994b; Melotto et al., 1996) to identify the dominant $I$ gene in the presence of the epistatic $b c-3$ gene as the desirable $I, b c-3$ combination cannot be distinguished from $i, b c-3$ genotypes using direct inoculation with strains of BCMNV (Kelly, 1997).

The introgression of recessive genes through traditional breeding is laborious and time consuming 
because of the need for progeny tests to identify genotypes with the desired resistance genes. Moreover, the epistatic interactions between resistance genes prevent direct selection for useful hypostatic genes, and require testcrosses to identify many useful resistance gene combinations. The use of indirect screening methods with molecular markers linked to the genes of interest would facilitate the development of bean cultivars with recessive resistance to BCMV and BCMNV. The recessive gene, $b c-3$, is particularly useful in areas of the world where BCMNV is prevalent since it confers resistance to all known strains of BCMNV and many strains of BCMV (Miklas et al., 1998). The use of marker-assisted-selection (MAS) by breeders should facilitate the transfer of the $b c-3$ gene into susceptible genotypes especially in those countries where TINI strains of BCMNV are absent or unavailable for screening due to quarantine restrictions.

A number of RAPD markers: OAD19690 linked $(1.9 \mathrm{cM})$ in coupling and OS $13_{660}$ linked $(7.1 \mathrm{cM})$ in repulsion to the $b c-3$ gene have been identified (Haley et al., 1994a). In addition, Johnson et al. (1997) developed SCAR markers from the OC11 $1550 / 420$ (ROC11) and $\mathrm{OC} 20_{460}$ RAPD markers linked to the $b c-3$ gene to improve their utilization. The use of these markers in MAS, however, has been limited due to a lack of polymorphism and reproducibility across diverse genetic backgrounds and gene pools of common bean (Kelly et al., 2003). Direct screening with strains of BCMV and $\mathrm{BCMNV}$ is still required to confirm the presence of the $b c-3$ gene. To efficiently introgress the $b c-3$ gene for resistance to BCMV and BCMNV into susceptible bean cultivars, there is a need to identify more robust DNA markers tightly linked to the $b c-3$ gene that will demonstrate reproducibility across laboratories and be functional in different genetic backgrounds. The objectives of this study were to use near-isogenic lines (NILs), segregating populations and DNA from different bean gene pools combined with the bulked segregant analysis (BSA), to increase the opportunity of finding new markers linked to $b c-3$ gene using both RAPD and AFLP analyses.

\section{Materials and methods}

\section{Mapping populations}

Three mapping populations representing different gene pools of common bean were used to screen for markers linked to the $b c-3$ gene. The Middle American gene pool was represented by a $\mathrm{F}_{4: 7}$ recombinant inbred line (RIL) population derived from a cross between cultivars Bunsi with the $I$ gene and Raven that carries the $I$, $b c-3$ gene combination (Kelly et al., 1994). The RILs were used to produce NILs that differed at the $b c-3$ locus, following a procedure outlined by Haley et al. (1994c). The genotype of the NILs was verified by inoculation with the NL 3 strain of BCMNV. The Andean population resulted from the cross between RWK10, a large seeded Rwandan dry bean cultivar with the $I$ gene (ISAR, 2001) and USCR-7 a cranberry bean genotype carrying the $I$ and $b c-3$ gene combination (Miklas \& Kelly, 2002). The parental reaction was verified after inoculation with the NL 3 strain of BCMNV. The $F_{1}$ generation was selfed to produce $\mathrm{F}_{2}$ individuals that segregated for the $b c-3$ gene but were fixed for the $I$ gene. Leaf samples for DNA extraction were collected from each $\mathrm{F}_{2}$ plant from the RWK10/USCR-7 population, and stored at $-80^{\circ} \mathrm{C}$. Each $\mathrm{F}_{2}$ plant was selfpollinated to produce $\mathrm{F}_{2: 3}$ families that were inoculated with the NL 3 strain of BCMNV to determine the genotype of the parental $F_{2}$ plant. An average of 10 or more seedlings from each $\mathrm{F}_{2: 3}$ family were mechanically rub inoculated with BCMNV following the methodology described by Kelly et al. (1995). The third mapping population was derived from the interracial cross between the breeding line BRB130 from CIAT, that carries the $I, b c-3$ gene combination and breeding line A25, derived from the Spanish cultivar Andecha, with no known genes for resistance to BCMNV. $\mathrm{F}_{2}$ plants were self-pollinated to produce $77 \mathrm{~F}_{2: 3}$ families but no direct screening for virus was conducted on the $\mathrm{F}_{2}$ individuals or $\mathrm{F}_{3}$ progeny. The genotype of $\mathrm{F}_{2}$ plants for the presence of the SCAR marker ROC11 linked to the $b c$-3 gene (Johnson et al., 1997), was determined after DNA collection and analysis of 10-12 plants of the corresponding $\mathrm{F}_{2: 3}$ families.

\section{RAPD analysis}

The search for RAPD markers linked to the $b c-3$ gene was carried out by screening random decamer primers (Operon Technologies, Alameda, CA and Integrated DNA Technologies, Coralville, IA). DNA extractions followed the mini-prep protocol of Afanador et al. (1993). PCR profile and agarose gel-electrophoresis conditions were similar to those of Haley et al. (1993), and BSA (Michelmore et al., 1991) was conducted in the RWK10/USCR-7 population using equimolar pools of DNA from five resistant individuals and five susceptible individuals. Primers shown to be polymorphic 
among Bunsi/Raven NILs were run on the parents and the DNA bulks of homozygous $\mathrm{F}_{2}$ individuals in the RWK10/USCR-7 population. Those primers that showed polymorphism between parents and bulks were subsequently tested on individual members of the bulks before testing on the complete population. In addition, RAPD markers putatively linked to $b c-3$ were tested for polymorphisms on the parental genotypes, BAT 93 and Jalo EEP558 of the integrated bean mapping population (Freyre et al., 1998). BSA was carried out in the A25/BRB130 population using equimolar pools of DNA from five homozygous individuals for positive and five homozygous individuals for negative amplification of the ROC11 marker. Those primers that showed polymorphism between parents and bulks were tested on the complete population. RAPD markers linked to ROC11 were tested for polymorphism in the Bunsi/Raven, RWK10/USCR-7 and BAT 93/Jalo EEP558 populations. The BAT 93/Jalo EEP558 population (Freyre et al., 1998), used to map polymorphic candidate markers to the integrated bean map, consisted of 64 RILs.

\section{AFLP analysis}

The search for a marker linked to $b c-3$ gene was conducted using AFLP analysis in combination with the same bulks described for RAPD analysis and silver staining techniques (Promega Madison, WI). The AFLP analysis followed previously described protocol by Hazen et al. (2002) using EcoRI and MseI as restriction enzymes. The gels were scored for polymorphisms between both between parents and bulks. The AFLP analysis was performed on the RWK10/USCR$7 \mathrm{~F}_{2}$ mapping population and the Bunsi/Raven RIL population.

\section{Sequence-tagged site (STS) marker development}

AFLP fragment(s) putatively linked to $b c-3$ were cloned following procedure previously described by Vallejo and Kelly (2002). A complete description of the protocol used to develop STS markers is available at www.css.msu.edu/bean. To confirm the conversion of the AFLP into a STS marker, PCR reactions were performed using the new primer combination on the parents and bulks before testing the entire mapping population. The optimal PCR amplification was conducted in $30 \mu \mathrm{l}$ reactions containing $30 \mathrm{ng}$ of template DNA, $0.5 \mathrm{ng}$ of each primer, $0.8 \mathrm{mM} \mathrm{dNTP}$ mix, $1 \times$ PCR buffer, $3.75 \mathrm{mM} \mathrm{MgCl}_{2}$, and $0.05 \mathrm{U}$ Taq DNA polymerase (Invitrogen, Carsbad, CA). DNA amplification was performed using Programmable Thermal Controller (PTC)-100 thermal cycler (MJ Research Inc., Waltham, MA) and the PCR profile consisted of $94^{\circ} \mathrm{C}$ for $2 \mathrm{~min}, 25$ cycles of $30 \mathrm{~s}$ at $94^{\circ} \mathrm{C}, 1 \mathrm{~min}$ at $53^{\circ} \mathrm{C}$, and $1 \mathrm{~min}$ at $72^{\circ} \mathrm{C}$ and the final extension of $5 \mathrm{~min}$ at $72^{\circ} \mathrm{C}$. To separate the amplified products, the PCR products were run on $6 \%$ polyacrylamide gels and visualized with the silver staining method (Promega, Madison WI).

\section{Segregation analysis}

A total of $77 \mathrm{~F}_{2}$ individuals from the A25/BRB130 population were screened for linkage between RAPD markers and the ROC11 SCAR. A group of $92 \mathrm{~F}_{2}$ individuals from the RWK10/USCR-7 population were originally screened for the putative RAPD, AFLP and STS markers, but as some of the $\mathrm{F}_{2: 3}$ families had less than 10 plants, verifiable phenotypic data was not adequate to confirm the $F_{2}$ phenotype. Since resistance was recessive, heterozygotes could still carry $b c-3$ allele but exhibit a susceptible phenotype. Progeny sizes under 10 plants per family were not included in the linkage analysis as they were considered too small to adequately separate between homozygous and heterozygous phenotypes. Heterozygous families of less than 10 plants, however, were included in the analysis. Using this criterion, only $58 \mathrm{~F}_{2}$ individuals were used to calculate segregation ratios and the linkage between the different markers and the disease reaction. The segregation for both molecular and phenotypic data for the $\mathrm{F}_{2}$ and $\mathrm{F}_{2: 3}$ generations of RWK10/USCR-7 and A25/BRB130 populations were analyzed to verify their goodness of fit with $1 \mathrm{R}: 3 \mathrm{~S}$ and $1 \mathrm{rr}: 2 \mathrm{Rr}: 1 \mathrm{RR}$ segregation ratios using the $\chi^{2}$-test.

\section{Linkage analysis}

The linkage analysis between the markers (RAPD, AFLP and STS) and the $b c-3$ gene or the ROC11 marker was performed using MAPMAKER 3.0 software (Lander et al., 1987) with a minimum LOD of 3.0. The recombination fraction was calculated using the Kosambi function. The same MAPMAKER 3.0 software was also used to map markers putatively linked to the $b c-3$ gene on the integrated map using the BAT 93/Jalo EEP558 RIL population. 


\section{Results}

RAPD analysis

A total of 1009 random primers were screened on the parents and the respective $\mathrm{R}$ and $\mathrm{S}$ bulks. One hundred sixty-eight primers $(16.6 \%)$ were polymorphic between Bunsi and Raven and 115 primers (11.4\%) were polymorphic between RWK10 and USCR-7, but none were polymorphic between the parents of both mapping populations. Four other primers were polymorphic between parents and bulks in the Bunsi/Raven population but none were linked to the $b c-3$ gene when tested on the entire mapping population. A total of 580 random primers were screened on the parents and bulks of the A25/BRB130 population. The RAPD markers OG6 $_{595}$ and OI4 775 were polymorphic and flanked the ROC11 marker at distances of $5.7 \mathrm{cM}$ and $6.2 \mathrm{cM}$, respectively (Figure 1a). Based on the close linkage between the ROC11 marker and the $b c-3$ gene (Johnson et al., 1997), OG6 595 and OI4 475 should flank the resistance gene. The OI4775 marker was not polymorphic in the other mapping populations and was not studied further. OG6 595 was also polymorphic between RWK10 and USCR-7 parents, and bulks and mapped at $3.7 \mathrm{cM}$ from the $b c-3$ gene in the RWK10/USCR-7 mapping population (Figure 1b). Segregation data was supported by the $\chi^{2}$ value $(0.45, p<0.575)$ for $1: 3$ ratio (Table 1). The $\mathrm{F}_{2}$ results of the phenotypic screening were confirmed by the analysis of the $F_{2: 3}$ families that showed a good fit $(p<0.375)$ to a segregation ratio of 1:2:1 supporting the presence of single recessive resistance gene (Table 1). The BAT/Jalo RIL mapping population was also screened with OG6 $_{595}$ to determine the marker location on the integrated bean linkage map. The OG6 595 marker mapped to linkage group B6 of the
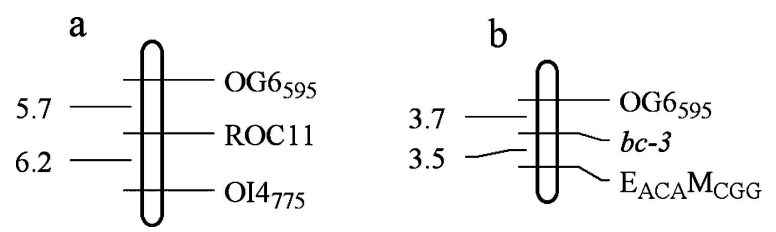

Figure 1. Linkage maps of markers flanking the ROC11 SCAR marker and the $b c-3$ gene on bean linkage group, B6; (a) Linkage map of RAPD markers OG6 595 and OI4 775 flanking the ROC11 marker (Johnson et al., 1997) in the A25/BRB130 population; (b) Linkage map of RAPD marker OG6595 and AFLP marker $\mathrm{E}_{A C A} \mathrm{M}_{C G G^{-}}$ $169 / 172$ flanking the $b c-3$ gene in the RWK10/USCR-7 population. Markers are shown on right side of figure and distances in $\mathrm{cM}$ are shown on the left side of the figure.
Table 1. Chi-square analysis of observed ratios for $b c-3$ gene and the AFLP marker $\mathrm{E}_{A C A} \mathrm{M}_{C G G^{-}} 169 / 172$ and $\mathrm{OG6}_{595}$ RAPD marker segregating for resistant (rr) and susceptible (R-) in $\mathrm{F}_{2}$ generation and for homozygous resistant (rr), heterozygous susceptible ( $\mathrm{Rr}$ ), and homozygous susceptible (RR) for $\mathrm{F}_{2: 3}$ families in RWK10/USCR-7 population

\begin{tabular}{llllll}
\hline $\begin{array}{l}\text { Locus } \\
\text { tested }\end{array}$ & Generation & $\begin{array}{l}\text { Expected } \\
\text { ratios }\end{array}$ & $\begin{array}{l}\text { Observed } \\
\text { ratios }\end{array}$ & $\chi^{2}$ & $P$ \\
\hline$b c-3$ & $\mathrm{~F}_{2}$ & $1: 3$ & $13: 45$ & 0.2 & 0.625 \\
$b c-3$ & $\mathrm{~F}_{2: 3}$ & $1: 2: 1$ & $13: 34: 11$ & 1.16 & 0.375 \\
$\mathrm{E}_{A C A} \mathrm{M}_{C G G}$ & $\mathrm{~F}_{2}$ & $1: 3$ & $10: 48$ & 1.86 & 0.175 \\
$\mathrm{E}_{A C A} \mathrm{M}_{C G G}$ & $\mathrm{~F}_{2: 3}$ & $1: 2: 1$ & $10: 36: 12$ & 3.52 & 0.175 \\
$\mathrm{OG}_{595}$ & $\mathrm{~F}_{2}$ & $1: 3$ & $12: 46$ & 0.45 & 0.575 \\
\hline
\end{tabular}

Resistant: $\mathrm{rr}=(b c-3, b c-3)$; Susceptible: R- $(B c-3, b c-3), \mathrm{RR}(B c-3$, $B c-3)$.

integrated bean map (Freyre et al., 1998) at $4.3 \mathrm{cM}$ from the previously mapped marker, ROC11 (Johnson et al., 1997) linked to the $b c-3$ gene on B6. The map distance $(4.3 \mathrm{cM})$ between OG6 $6_{595}$ and ROC11 in BAT/Jalo population approximated the linkage distance $(3.7 \mathrm{cM})$ between OG6 595 and $b c-3$ in the RWK10/USCR-7 population (Figure 1b) and the linkage distance $(5.7 \mathrm{cM})$ between OG6 $_{595}$ and ROC11 in the A25/BRB130 population (Figure 1a). The DNA fragment corresponding to RAPD OG6 595 obtained from BRB130, was purified, cloned, sequenced, and the SCAR primers $5^{\prime}$ - GTGCCTAACCGAGTTATCTAGAGT-3' and $5^{\prime}$-GTGCCTAACCCTCCTAAATGACCT-3' were designed (the sequence corresponding to the RAPD is underlined). These primers amplified a single DNA fragment of the expected size $(595 \mathrm{bp})$ in all materials analyzed, but no polymorphisms were observed between genotypes under the most stringent conditions. The sequence of the amplification product obtained from A25 as template was determined and proved identical to the original fragment obtained from BRB130. Attempts to produce a polymorphic SCAR marker of the OG6595 RAPD marker were unsuccessful.

\section{AFLP analysis}

A total of 42 primer-pair combinations were screened against parents and bulks in the RWK10/USCR-7 population. Twelve primer combinations $(20.5 \%)$ generated at least one polymorphism between parents and a total of 23 polymorphisms were generated. Out of 12 primer combinations, 5 were polymorphic between both parents and bulks. When individual members of the bulks were examined one co-dominant 
marker $\mathrm{E}_{A C A} \mathrm{M}_{C G G^{-}}$169/172 co-segregated with the disease reaction (Table 1). The co-segregating bands were approximately $169 / 172 \mathrm{bp}$ in size and the smaller fragment was associated with resistance $(p<0.175$; Figure 1b). This AFLP marker was tested in the entire mapping population but only $58 \mathrm{~F}_{2}$ individuals were used to calculate the linkage between the $\mathrm{E}_{A C A} \mathrm{M}_{C G G 169 / 172}$ marker and the disease reaction. The linkage analysis showed that $\mathrm{E}_{A C A} \mathrm{M}_{C G G 169 / 172}$ marker was linked at $3.5 \mathrm{cM}$ distance from the $b c-3$ gene and was supported by the $\chi^{2}$ value $(1.86, p<0.175)$ for $1: 3$ ratio (Table 1$)$. The AFLP and OG6 595 markers flanked the $b c-3$ gene (Figure $1 \mathrm{~b}$ ).

To facilitate scoring and reduce the costs associated with the AFLP analysis by eliminating the digestion and ligation steps, the $\mathrm{E}_{A C A} \mathrm{M}_{C G G^{-}}$ $169 / 172$ marker was transformed into the STS marker $\mathrm{SE}_{A C A} \mathrm{M}_{C G G}$. The $169 \mathrm{bp}$ fragment corresponding with resistance phenotype was sequenced and two primers combinations were designed to amplify codominant 134/137 bp fragments (Figure 2). The smaller size of the fragments generated by the STS marker compared to the AFLP marker was due to the elimination of the sequence corresponding to AFLP adapters used in designing primers. The sequences of the primers synthesized were $5^{\prime}$ CGGTCATACATTTATACAAAACC- $3^{\prime}$ for the forward primer and 5'-AGTTTGACAGGTGCAAGTCT$3^{\prime}$ for the reverse primer. The $\mathrm{SE}_{A C A} \mathrm{M}_{C G G^{-134 / 137}}$ marker generated bands of the same pattern as the original AFLP and resulted in the same number of recombinants. A diverse group of bean genotypes known to carry the $b c-3$ gene in the kidney, pinto, black, cranberry, small red, and great northern commercial classes representing the two gene pools of common bean were tested for the presence of the $\mathrm{SE}_{A C A} / \mathrm{M}_{C G G^{-134 / 137}}$ marker (Table 2). The band linked to resistance was
Table 2. Survey of bean genotypes carrying $b c-3$ gene for presence of $\mathrm{SE}_{A C A} \mathrm{M}_{C G G^{-134 / 137 ~ a n d ~ O G 6595 ~ m a r k e r s ~}}$

\begin{tabular}{lllll}
\hline Genotypes & $\begin{array}{l}\text { Gene } \\
\text { pool }^{\text {a }}\end{array}$ & $\begin{array}{l}\text { Bean } \\
\text { class }\end{array}$ & $\begin{array}{l}\text { Band } \\
\text { size (bp) }\end{array}$ & $\begin{array}{l}\text { RAPD } \\
\text { OG6595 }\end{array}$ \\
\hline USCR-7 & A & Cranberry & 134 & $+^{\mathrm{c}}$ \\
USCR-9 & A & Cranberry & 134 & + \\
USLK-2 & A & Light red kidney & 137 & + \\
USDK-4 & A & Dark red kidney & 137 & + \\
USWK-6 & A & White kidney & 134 & + \\
PR0066-6 & MA & Small red & 134 & + \\
I99530 & MA & Small red & 134 & + \\
I99532 & MA & Small red & 134 & + \\
Raven & MA & Black & 134 & + \\
B00108 & MA & Black & 134 & + \\
BDM-RMR-11 & MA & Pinto & 134 & + \\
BDM-RMR-16 & MA & Pinto & 134 & + \\
BDM-RMR-19 & MA & Pinto & 134 & + \\
G99750 & MA & Great northern & 134 & + \\
RWK10 & A & Large red stripe & 137 & - \\
Bunsi & MA & Navy & 134 & + \\
\hline & & & + \\
\hline
\end{tabular}

a A: Andean; MA: Middle America; 134 base pairs: Resistance band; 137 bp: Susceptibility band.

${ }^{\mathrm{b}}$ Susceptible check cultivars, lacking the $b c-3$ gene.

${ }^{c}+$ : Presence; $-:$ absence of the OG6 ${ }_{595}$ marker.

present in all lines possessing $b c$-3, except in two kidney lines USLK-2, USDK-4 and Bunsi (Table 2).

\section{Discussion}

NILs from the Middle American gene pool originating from the Bunsi/Raven population were first used to find a RAPD marker linked to $b c-3$ gene. The efficiency of NILs for targeting RAPD markers linked to disease resistance genes was suggested by Haley et al. (1994c)

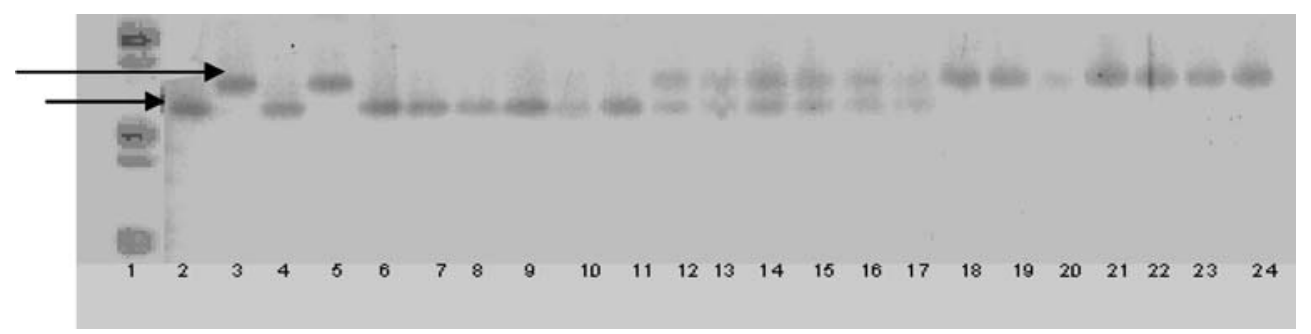

Figure 2. PCR product obtained using the $\mathrm{SE}_{A C A} \mathrm{M}_{C G G}-134 / 137$ STS marker; Arrows indicate 134 bp lower band associated with resistance; 137 bp upper band associated with susceptibility; Lane 1. 10 bp ladder; Lane 2. resistant parent (USCR-7); Lane 3. susceptible parent (RWR 10); Lane 4. resistant bulk; Lane 5. susceptible bulk; Lanes 6-11. F 2 resistant individuals; Lanes 12-17. F heterozygote individuals; Lanes 18-24. $\mathrm{F}_{2}$ susceptible individuals. 
as a strategy to reduce the number of false positive polymorphisms, and enhance the likelihood of finding tighter linkages to the gene of interest. In this study, primers that generated polymorphisms between NILs in the Middle American gene pool were tested on parents and bulks from the Andean gene pool. Combining these two strategies with BSA, which reduces targeted markers to a smaller region within the genome, was expected to facilitate and improve the finding of a more robust marker linked to $b c-3$ gene. These strategies reduced the incidence of false positive bands since only a small number of polymorphic primers between both parents and bulks were observed compared to the number of primers tested. Only one RAPD marker OG6 ${ }_{595}$, however, proved to be linked with the $b c-3$ resistance gene in the Andean population. This marker provided the opportunity to reconfirm the map location of the $b c-3$ gene on B6 (Kelly et al., 2003). Markers linked in repulsion phase to other recessive genes such as the $b c$ $l^{2}$ and $b g m-1$ genes conditioning resistance to BCMV and BGMV, respectively have been reported in common bean (Miklas et al., 2000; Urrea et al., 1996) but finding markers linked to a recessive resistance genes in the host has proved challenging.

The genetic variability observed between parents was higher between Bunsi and Raven (16.6\%) than between USCR-7 and RWK10 (11.4\%). A similar increased molecular variability in the Middle America gene pool was also observed by Beebe et al. (2000, 2001), who concluded that a narrower genetic base existed in Andean gene pool. Greater genetic variability was detected between USCR-7 and RWK10 genotypes by the AFLP than by the RAPD analysis. In only 42 primer pair combinations $20.5 \%$ were polymorphic between the Andean parents suggesting that this technique may be more powerful than RAPD in detecting polymorphism among highly related genetic material. The AFLP technique enabled us to find a codominant marker tightly linked $(3.5 \mathrm{cM})$ to $b c-3$ gene in a relatively small population of $58 \mathrm{~F}_{2}$ plants. The codominant nature of the AFLP and STS markers detected in this study is particularly useful in breeding for the recessive $b c-3$ gene. Codominant markers can help in the identification of heterozygous individuals at each generation, eliminating the number of generations required for progeny testing. However it was not possible to visualize the polymorphism generated by the $\mathrm{SE}_{A C A} \mathrm{M}_{C G G^{-}}$ $134 / 137$ marker on agarose gels. This is due to the small 3 bp difference between fragments which cannot be resolved as effectively on agarose gels as on polyacrylamide gels (Figure 2).
The fragment associated with the resistance phenotype generated by the $\mathrm{SE}_{A C A} \mathrm{M}_{C G G^{-134 / 137 ~ m a r k e r ~}}$ was present in genotypes of pinto, cranberry, small red, black, and great northern beans known to carry the $b c$ 3 gene (Table 2). This association suggests that the marker could be useful for MAS in those distinct seed classes. In kidney beans, the resistance-associated band was present in USWK-6, but was absent in the resistant USLK-2 and USDK-4 genotypes. These results suggest that the marker should be tested in a larger number of kidney beans to ascertain its usefulness in this class and that recombination could have occurred between the marker and the $b c-3$ gene during the repeated backcrossing used to develop the resistant USLK-2 and USDK-4 kidney bean lines with $b c-3$ (Miklas et al.,

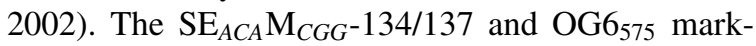
ers should facilitate marker-assisted breeding for $b c-3$ gene and hasten the development of BCMNV resistant bean cultivars. Importantly these markers should offer the unique opportunity to develop cultivars with the $I$ and $b c-3$ gene pyramid which is recognized to confer resistance to all known strains of BCMV and BCMNV in common bean.

\section{Acknowledgements}

The authors wish to recognize Project PEARL (USAID project no. HNE-A-00-97-00059-00) for providing financial support for G. Mukeshimana; the work developed at the University of Oviedo was supported by grants AGL2001-2676-CO2 and RTA02-052-C2 from the Ministerio de Ciencia y Tecnología, Spain; Astrid Pañeda is recipient of a salary fellowship from the Fundación para el Fomento de la Investigación Científica y Tecnológica (FICYT), Principado de Asturias, Spain; Cristina Rodríguez-Suárez is recipient of a salary fellowship from the Ministerio de Ciencia y Tecnología, Spain; the valuable assistance of V. Vallejo in the development and running of the AFLP and STS marker protocols used in this study [Protocols are available at www.css.msu.edu/bean], and for the execution of MAPMAKER 3 software program; and to B. Román Avilés for general lab assistance and support.

\section{References}

Afanador, L.K., S.D. Haley \& J.D. Kelly, 1993. Adoption of miniprep DNA extraction method for RAPD marker analysis in common bean (Phaseolus vulgaris). Annu Rep Bean Improv Coop 36: 10-11. 
Ali, M.A., 1950. Genetics of resistance to the common bean mosaic virus in the bean (Phaseolus vulgaris L.). Phytopathology 40: 69-79.

Beebe, S., P.W. Skroch, J. Tohme, M.C. Duque, F. Pedroza \& J. Nienhuis, 2000. Structure of genetic diversity among common bean landraces of Middle American origin based on correspondence analysis of RAPD. Crop Sci 40: 264-273.

Beebe, S., J. Rengifo, E. Gaitan, M.C. Duque \& J. Tohme, 2001. Diversity and origin of Andean landraces of common bean. Crop Sci 41: 854-862.

Coyne, D.P., J.R. Steadman, G. Godoy-Lutz, R. Gilbertson, E. Arnaud-Santana, J.S. Beaver \& J.R. Myers, 2003. Contribution of the Bean/Cowpea CRSP to management of bean disease. Field Crops Res 82: 87-102.

Drijfhout, E., 1978. Genetic interaction between Phaseolus vulgaris and bean common mosaic virus with implications for strain identification and breeding resistance. Agric Res Rep 872: 1-98. Centre for Agriculture Publishing and documentation, Wageningen, Netherlands.

Drijfhout, E., 1991. Bean common mosaic. In: R. Hall (Ed.), Compendium of Bean Diseases, pp. 37-39. APS Press, St. Paul, MN.

Flores-Estévez, N., J.A. Acosta-Gallegos \& L. Silva-Rosales, 2003. Bean common mosaic virus and bean common mosaic necrosis virus in Mexico. Plant Dis 87: 21-25.

Fraser, R.S., 1992. The genetics of plant-virus interactions: Implications for plant breeding. Euphytica 63: 175-1992.

Freyre, R., P.W. Skroch, V. Geffroy, A.F. Adam-Blondon, A. Shirmohamadali, W.C. Johnson, V. Llaca, R.O. Nodari, P.A. Pereira, S.M. Tsai, J. Tohme, M. Dron, J. Nienhuis, C.E. Vallejos \& P. Gepts, 1998. Towards an integrated linkage map of common bean. 4. Development of a core linkage map and alignment of RFLP maps. Theor Appl Genet 97: 847-856.

Gepts, P., 1999. Development of an integrated linkage map. In: S.P. Singh (Ed.), Development in plant breeding. Common bean improvement in the twenty-first century, pp. 53-91. Kluwer Academic Publisher, Dordrecht, The Netherlands.

Haley, S.D., P.N. Miklas, J.R. Stavely, J. Byrum \& J.D. Kelly, 1993. Identification of RAPD markers linked to a major rust resistance gene block in common bean. Theor Appl Genet 86: 505512 .

Haley, S.D., L. Afanador \& J.D. Kelly, 1994a. Selection for monogenic pest traits with coupling and repulsion phase RAPD markers. Crop Sci 34: 1061-1066.

Haley, S.D., L. Afanador \& J.D. Kelly, 1994b. Identification and application of a random amplified polymorphic DNA marker for the I gene (potyvirus resistance) in common bean. Phytopathology 84: $157-160$.

Haley, S.D., L. Afanador \& J.D. Kelly, 1994c. Heterogeneous inbred populations are useful as sources of near-isogenic lines for RAPD marker localization. Theor Appl Genet 88: 337-342.

Harrison, B.D., 2002. Virus variation in relation to resistance breaking in plants. Euphytica 124: 181-192.

Hart, L.P. \& A.W. Saettler, 1981. Bean common mosaic virus. Michigan State University, Extension Bulletin E-1561.

Hazen, S.P., P. Leroy \& R.W. Ward, 2002. AFLP in Triticum aestivum L.: Pattern of genetic diversity and genome distribution. Euphytica 125: 89-102.

ISAR, Bean program, 2001. Activity review, August 2001. p 1-8. http://www.isar.cgiar.org/Isarprog/Bean.htm

Johansen, I.E., O.S. Lund, C.K. Hjulsager \& J. Laursen, 2001. Recessive resistance in Pisum sativum and potyvirus pathotype resolved in gene for cistron correspondence between host and virus. J Virol 75: 6609-6614.

Johnson, W.C., P. Guzman, D. Mandala, A.B.C. Mkandawire, S. Temple, R.L. Gilbertson \& P. Gepts, 1997. Molecular tagging of $b c-3$ gene for introgression into Andean common bean. Crop Sci 37: 248-254.

Kelly, J.D., 1997. A review of varietal response to bean common potyvirus in Phaseolus vulgaris. Plant Varieties Seeds 10: 1-6.

Kelly, J.D., A.W. Saettler \& M.W. Adams, 1983. New necrotic strain of bean common mosaic virus in Michigan. Annu Rep Bean Improv Coop 26: 49-50.

Kelly, J.D., G.L. Hosfield, G.V. Varner, M.A. Uebersax, S.D. Haley \& J. Taylor, 1994. Registration of 'Raven' black bean. Crop Sci 34: 1406-1407.

Kelly, J.D., L. Afanador \& S.D. Haley, 1995. Pyramiding genes for resistance to bean common mosaic virus. Euphytica 82: 207212.

Kelly, J.D., P. Gepts, P.N. Miklas \& D.P. Coyne, 2003.Tagging and mapping of genes and QTL and molecular-marker assisted selection for traits of economic importance in bean and cowpea. Field Crops Res 82: 135-154.

Lander, E.S., P. Green, J. Abrahamson, A. Barlow, M.J. Daly, S.E. Lincoln \& L. Newburg, 1987. MAPMAKER: An interactive computing package for constructing primary genetic linkage maps of experimental and natural populations. Genomics 1: 174-181.

McKern, N.M., G.I. Mink, O.W. Barnett, A. Mishra, L.A. Whittaker, M.J. Silbernagel, C.W. Ward \& D.D. Shukla, 1992. Isolates of bean common mosaic virus comprising two distinct potyviruses. Phytopathology 82: 923-928.

Melotto, M., L. Afanador \& J.D. Kelly, 1996. Development of a SCAR marker linked to the $I$ gene in common bean. Genome 39: 1216-1219.

Michelmore, R.W., I. Paran \& R.V. Kesseli, 1991. Identification of marker linked to disease resistance genes by bulked segregant analysis: A rapid method to detect markers in specific genomic regions by using segregating populations. Proc Natl Acad Sci 88: 9828-9832.

Miklas, P.N., S. Lambert, G. Mink \& M. Silbernagel, 1998. Many beans with $b c-3$ resistance to BCMNV are susceptible to BCMV. Annu Rep Bean Improv Coop. 41: 33-34.

Miklas, P.N., R.C. Larsen, R. Riley \& J.D. Kelly, 2000. Potential marker assisted selection for $b c-1^{2}$ resistance to bean common mosaic potyvirus in common bean. Euphytica 116: 211-219.

Miklas, P.N., A.N. Hang, J.D. Kelly, C.A. Strausbaugh \& R.L. Forster, 2002. Registration of three kidney bean germplasm lines resistant to bean common mosaic virus and necrosis potyviruses: USLK-2 light red kidney, USDK-4 dark red kidney, and USWK-6 white kidney. Crop Sci 42: 674-675.

Miklas, P.N. \& J.D. Kelly, 2002. Registration of two cranberry bean germplasm lines resistant to bean common mosaic and necrosis potyviruses: USCR-7 and USCR-9. Crop Sci 42: 673-674.

Njau, P.J.R. \& H.F.J. Lyimo, 2000. Incidence of bean common mosaic virus and bean common mosaic necrosis virus in bean (Phaseolus vulgaris $L$.) in the wild legumes seedlots in Tanzanian Seed. Sci Technol 28: 85-92.

Provvidenti, R., M.J. Silbernagel \& W.Y. Wang, 1984. Local epidemic of NL-8 strain of bean common mosaic virus in bean fields of western New York. Plant Dis 68: 1092-1094.

Revers, F., O. Le Gall, T. Candresse \& A.J. Maule, 1999. New advances in understanding the molecular biology of plant/potyvirus interactions. Mol Plant-Microbe Interact 12: 367-376. 
Sáiz, M., C. De Blas, G. Carazo, J. Fresno, J. Romero \& S. Castro, 1995. Incidence and characterization of bean common mosaic virus isolates in Spanish bean fields. Plant Dis 79: 7981.

Sengooba, T.N., N.J. Spence, D.G.A. Walkey, D.J. Allen \& A. Femi Lana, 1997. The occurrence of bean common mosaic necrosis virus in wild and forage legumes in Uganda. Plant Pathol 46: 95-103.

Silbernagel, M.J., L.J. Mills \& W.Y. Wang, 1986. Tanzanian strain of bean common mosaic virus. Plant Dis 70: 839-841.

Silbernagel, M.J., G.I. Mink, R.-L. Zhao \& G.-Y. Zheng, 2001. Phenotypic recombination between bean common mosaic and bean common mosaic necrosis potyviruses in vivo. Arch Virol 146: 1007-1020.

Spence, N.J. \& D.G.A. Walkey, 1995. Variation for pathogenicity among isolates of bean common mosaic virus in Africa and reinterpretation of the genetic relationship between cultivars of Phase- olus vulgaris and pathotypes of BCMV. Plant Pathol 44: 527546.

Strausbaugh, C.A., J.R. Myers, R.L. Forster \& P.E. McClean, 1999. $B c-1$ and $B c-u$ two loci controlling bean common mosaic virus resistance in common bean are linked. J Am Soc Hort Sci 124: 644-648.

Tu, J.C., 1986. Isolation and characterization of a new necrotic strain (NL-8) of bean common mosaic virus in Southwestern Ontario. Can Plant Dis Surv 66: 13-14.

Urrea, C.A., P.N. Miklas, J.S. Beaver \& R.H. Riley, 1996. A codominant randomly amplified polymorphic DNA (RAPD) marker useful for indirect selection of bean golden mosaic virus resistance in common bean. J Am Soc Hort Sci 121: 1035-1039.

Vallejo, V. \& J.D. Kelly, 2002. The AFLP analysis to tag the $\mathrm{Co}-\mathrm{I}^{2}$ gene conditioning resistance to bean anthracnose. Plant and animal genome X conference 2002. http://www.intpag.org/pag/10/abstracts/PAGX P233.html 